\title{
MANAGEMENT LESSONS FROM ITALY: A BIBLIOMETRIC ANALYSIS OF TOP ITALIAN BASED SCHOLARS AND STUDIES PUBLISHED FROM 1985 TO 2015.
}

\author{
Published on International Journal of Critical Accounting
}

Marzi, G., Caputo, A., \& Dabić, M. (2017). Management lessons from Italy: A bibliometric analysis of top Italian based scholars and studies published from 1985 to 2015. International Journal of Critical Accounting, 9(4), 269288. DOI: https://doi.org/10.1504/IJCA.2017.089379

\section{Giacomo Marzi}

University of Lincoln, UK

\section{Andrea Caputo}

University of Lincoln, UK

\section{Marina Dabić}

University of Zagreb, HR

Nottingham Trent University, UK

\begin{abstract}
Based on three decades of data collected via Web of Science (WOS) database this paper offers a comprehensive overview of Italian managerial studies published in international journals indexed in the WOS Core Collection. This paper, taking in consideration 1,665 researches made by Italian scholars or based in the Italian context, firstly shows the most influential papers, authors, and the most relevant journals. Using a keywords co-occurrences analysis the paper shows the most relevant topics, how they are clustered together, and the relative importance in terms of number of citations. Finally, it provides a representation of keywords average novelty highlighting the past, the present, and the future trends in Italian managerial studies.
\end{abstract}

Keywords: Italian, management, bibliometric, literature, review, keywords, clustering, scholar, Italian studies, top journals, web of science, WOS, VOS, VOSviewer. 


\section{Introduction}

The Italian management school owes its origins to Gino Zappa (Zappa, 1927) who first introduced the importance of management in the Italian thought. As pointed out by Coda (2002), Zappa was the first Italian author who explored the various functions of every firm, showing how the firm is embodied in a complex set of connections between itself and the environment in which it operates. Thus, the firm requires a separate set of functions related to its particular aspect, i.e. management and accounting. The importance of Zappa's works was highlighted by Caprara (1961) who showed how every post-war Italian study was indeed influenced by Zappa's thought.

After Gino Zappa, the Italian management school produced a consistent amount of management related studies, however, until the mid-90s the Italian knowledge base related to this topic was published almost only in books, book series and essays in the Italian language (Carmona, 2006). Most likely, the biggest limitation to the international diffusion of Italian management school was related to the language barrier that choked the global spread of it. Similar to other European schools, e.g. the French or Spanish (Wren, 2005; Carmona, 2006), this did not allow the Italian school to have a broader international recognition even though it presented innovative and groundbreaking ideas.

Since the second half of the nineties Italian management scholars have focused their attention on publishing in international scientific journals in the English language, allowing a gradual international spread of the Italian school of thoughts.

Thus, the aim of the present study is to investigate the contributions of Italian scholars or Italian-based management studies through a bibliometric analysis of the research published from 1985 to 2015. Indeed, bibliometric studies have shown their effectiveness in a broad range of fields such as management (Podsakoff et al., 2008; Dabic et al., 2014; 2015), entrepreneurship (Landström et. al 2012, Marzi et al., 2017), operations management (Hsieh \& Chang, 2009) and innovation (Fagerberg et al, 2012), helping scholars to navigate the expanding universe of scientific papers. Therefore, the collected data covers three decades of research in that field (1985-2015), providing a full perspective on it.

With this paper, we aim to take a picture of the actual situation showing different data: the top journals, top papers and a keywords analysis to identify specific areas of interest. In particular, with the keyword analysis, we want to define the major topics of Italian management studies. For this 
purpose, we propose a comprehensive bibliometric analysis of Italian management studies from 1985 to 2015 indexed in WOS Core Collection database.

Specifically, regarding the keyword analysis, we present three levels of detail. The first regards the keyword clusters and highlights how the topics are joining in creating research fields. The second level represents the intensity of each keyword, showing the relevance of each topic and arguments in the knowledge base taken into consideration. The third level, which is important to analyze the future directions of the Italian-based studies, examines the average novelty of the keywords on the basis of average age of their appearances on papers.

Based on this information we can trace the past, the present and the future of Italian-based scholar and Italian-based studies and give some useful insights for future trends in this field of study.

Thus, the aim of this paper is twofold. In the first part, namely paragraph two, we present the analysis of the date in order to give a snapshot of the past and the present. In the second part, based on the keyword analysis we present the major area of interest tracing the future path of the evolution of the field taken into consideration.

\section{Literature Analysis}

\subsection{Data Gathering}

The first step of the research process concerned sample selection; because of this we have selected Thomson Reuters Web of Science ${ }^{\mathrm{TM}}$ database. In particular, inside that database, we have selected Web of Science Core Collection as it offers the most valuable and high-impact collection of papers (Franceschet, 2010). The journals included in Web of Science Core Collection have met the high standards regarding impact factor and number of citations.

The indexes covered by the data gathering are: Science Citation Index Expanded, Social Sciences Citation Index, and Arts \& Humanities Citation Index. These indexes containing journals that rank competitively among the most highly cited core journals in their category or categories, covering only the most highly cited, highest impact journals in each category (Leydesdorff et al., 2013).

The research query to get the preliminary set of data have been done on June, 13th 2016 with the following research terms limited to "English" as language, "Article" as document types and time span 1985-2015:

$$
T S=\left(" m a n a{ }^{*} "\right) A N D(T S=(" i t a l * ") \text { OR } C U=(\text { "italy")) }
$$


Where "TS" mean "Topic" in Advanced Research page, and "CU" means the country of the author's institution. The initial search found 52,320 results in all research areas; this was then refined by applying "Business and Economics" as the research area, resulting in 2,629 papers. Finally, a third filter was adopted by using WOS categories of "business" and "management" which resulted in a final dataset of 1,665 papers. A manual screening was operated to ensure that all journals matched the inclusion criteria. In the next sections, we present the analysis of the extracted dataset. Regarding section two, we used Microsoft Excel 2016 and Rapid Miner Studio 7.3 to operationalize the data mining algorithm (Hofmann and Klinkenberg, 2013). Data analysis of section three is done by a specific bibliometric routine that is discussed later.

\subsection{Papers Overview}

Table 1 shows years, number of papers (N.P.), and percentage variation compared to previous year (P.V.).

Table 1 - Papers distributions among years

\begin{tabular}{|c|c|c|c|c|c|}
\hline Year & N. P. & P.V. & Year & N.P. & P.V. \\
\hline 1985 & 1 & --- & 2001 & 28 & $+47 \%$ \\
\hline 1986 & 2 & $+100 \%$ & 2002 & 40 & $+43 \%$ \\
\hline 1987 & 1 & $-50 \%$ & 2003 & 36 & $-10 \%$ \\
\hline 1988 & 0 & $-100 \%$ & 2004 & 34 & $-6 \%$ \\
\hline 1989 & 1 & $+100 \%$ & 2005 & 46 & $+35 \%$ \\
\hline 1990 & 0 & $-100 \%$ & 2006 & 40 & $-13 \%$ \\
\hline 1991 & 0 & $0 \%$ & 2007 & 56 & $+40 \%$ \\
\hline 1992 & 4 & $+400 \%$ & 2008 & 68 & $+21 \%$ \\
\hline 1993 & 8 & $+100 \%$ & 2009 & 107 & $+57 \%$ \\
\hline 1994 & 8 & $0 \%$ & 2010 & 115 & $+7 \%$ \\
\hline 1995 & 14 & $+75 \%$ & 2011 & 132 & $+15 \%$ \\
\hline 1996 & 25 & $+79 \%$ & 2012 & 167 & $+27 \%$ \\
\hline 1997 & 21 & $-16 \%$ & 2013 & 164 & $-2 \%$ \\
\hline 1998 & 27 & $+29 \%$ & 2014 & 209 & $+27 \%$ \\
\hline 1999 & 23 & $-15 \%$ & 2015 & 269 & $+29 \%$ \\
\hline 2000 & 19 & $-17 \%$ & Total P. & \multicolumn{1}{|c|}{$\mathbf{1 , 6 6 5}$} \\
\hline & \multicolumn{7}{|c|}{$*$ NP is number of papers } \\
\hline P.V.is percentage variation compared to previous year \\
\hline
\end{tabular}

A graphical illustration can help to represent the magnitude of the phenomena better. Data collected showed the following distribution among the years are shown in Figure 1. 
Figure 1 - Graphical representation of papers distributions among years

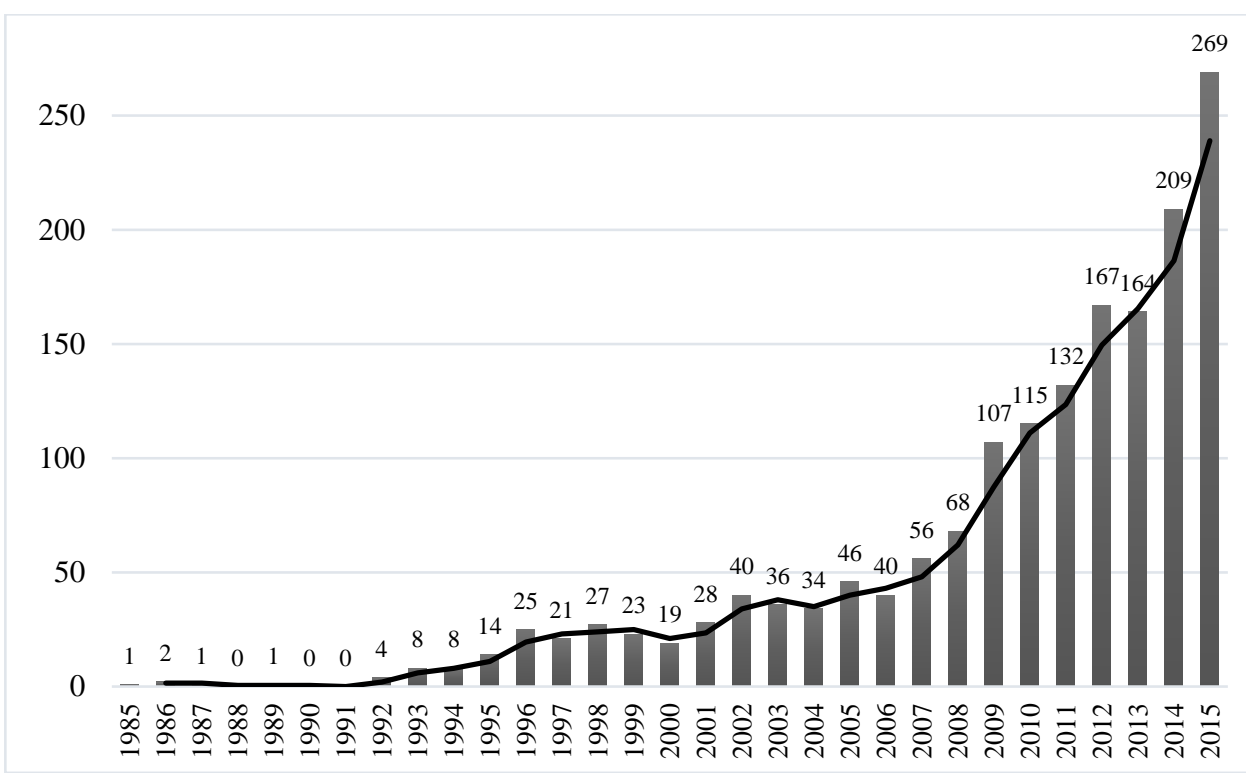

Despite the time span being set during 1985-2015, the first relevant cluster of papers appeared only in 1992. After this period, the academic interest in this field slowly grew until 2008. From Figure 1 is possible to see that this area of research then had a faster growth from 2008 to 2015 with an average of 153.87 papers per year and an average growth rate of $23 \%$ in this time span.

An insight which emerges from the dataset is probably connected with the introduction of the "Agenzia nazionale di valutazione del sistema universitario e della ricerca" (ANVUR), the Italian institution devoted to evaluating the quality of Italian research and university system (e.g. equivalent to the REF in the UK). The agency assesses the quality of processes, results, and products of teaching and research, including the technology transfer, universities and research institutions supervised by the Ministry of Education, University and Research (MIUR). ANVUR was created in 2006, and as data showed after this year, the number of scientific Italian indexed publication dramatically increases over the years since then. Data illustrate how the introduction of new rules for promotion and funding pushed Italian scholars to internationalize their scientific production.

Taking into consideration the single publications, Table 2 shows the 20 most cited papers according to WOS. TC means Times Cited and the data are updated to the day of data gathering, namely June, 13th 2016. The TC value presented in this table apparently differs by Google Scholar number of citation. As an example, the first paper on the table below by Lorenzoni 
and Lipparini has a Google Scholar number of citation equal to 1493 times. However, the Google's measure takes into consideration also weak impact and not indexed publication. Web of Science Core Collection counts only citations from articles published in high quality and high-impact journals. For this study, that is to trace only the highest impact publication, WOS counting is more appropriate (Meho and Yang, 2007).

Table 2 - Twenty most cited paper according to WOS

\begin{tabular}{|c|c|c|c|c|}
\hline TC & Author(s) & Title & Year & Journal \\
\hline 398 & $\begin{array}{l}\text { Lorenzoni, G. } \\
\text { Lipparini, A. }\end{array}$ & $\begin{array}{l}\text { The leveraging of interfirm } \\
\text { relationships as a distinctive } \\
\text { organizational capability: A } \\
\text { longitudinal study. }\end{array}$ & 1999 & $\begin{array}{l}\text { Strategic } \\
\text { management } \\
\text { journal }\end{array}$ \\
\hline 350 & $\begin{array}{l}\text { Gargiulo, M. } \\
\text { Benassi, M. }\end{array}$ & $\begin{array}{l}\text { Trapped in your own net? Network } \\
\text { cohesion structural holes, and the } \\
\text { adaptation of social capital. }\end{array}$ & 2000 & $\begin{array}{l}\text { Organization } \\
\text { science }\end{array}$ \\
\hline 252 & Bonaccorsi, A. & $\begin{array}{l}\text { On the relationship between firm } \\
\text { size and export intensity. }\end{array}$ & 1992 & $\begin{array}{l}\text { Journal of } \\
\text { international } \\
\text { business studies }\end{array}$ \\
\hline 250 & $\begin{array}{l}\text { Gibbert, M. } \\
\text { Ruigrok, W. } \\
\text { Wicki, B. } \\
\end{array}$ & $\begin{array}{l}\text { What passes as a rigorous case } \\
\text { study? }\end{array}$ & 2008 & $\begin{array}{l}\text { Strategic } \\
\text { management } \\
\text { journal }\end{array}$ \\
\hline 249 & $\begin{array}{l}\text { Mudambi, R. } \\
\text { Navarra, P. }\end{array}$ & $\begin{array}{l}\text { Is knowledge power? Knowledge } \\
\text { flows, subsidiary power and rent- } \\
\text { seeking within MNCs. }\end{array}$ & 2004 & $\begin{array}{l}\text { Journal of } \\
\text { international } \\
\text { business studies }\end{array}$ \\
\hline 206 & Verona, G. & $\begin{array}{l}\text { A resource-based view of product } \\
\text { development. }\end{array}$ & 1999 & $\begin{array}{l}\text { Academy of } \\
\text { management review }\end{array}$ \\
\hline 194 & $\begin{array}{l}\text { Greco, S. } \\
\text { Matarazzo, B. } \\
\text { Slowinski, R. }\end{array}$ & $\begin{array}{l}\text { Rough sets methodology for } \\
\text { sorting problems in presence of } \\
\text { multiple attributes and criteria. }\end{array}$ & 2002 & $\begin{array}{l}\text { European journal of } \\
\text { operational research }\end{array}$ \\
\hline 190 & Forza, C. & $\begin{array}{l}\text { Survey research in operations } \\
\text { management: a process-based } \\
\text { perspective. }\end{array}$ & 2002 & $\begin{array}{l}\text { International } \\
\text { journal of } \\
\text { operations \& } \\
\text { production } \\
\text { management }\end{array}$ \\
\hline 188 & Capaldo, A. & $\begin{array}{l}\text { Network structure and innovation: } \\
\text { The leveraging of a dual network } \\
\text { as a distinctive relational } \\
\text { capability. }\end{array}$ & 2007 & $\begin{array}{l}\text { Strategic } \\
\text { management } \\
\text { journal }\end{array}$ \\
\hline 183 & $\begin{array}{l}\text { Colombo, M.G. } \\
\text { Grilli, L. }\end{array}$ & $\begin{array}{l}\text { Founders' human capital and the } \\
\text { growth of new technology-based } \\
\text { firms: A competence-based view. }\end{array}$ & 2005 & Research policy \\
\hline 175 & $\begin{array}{l}\text { Chiesa, V. } \\
\text { Coughlan, P. } \\
\text { Voss, C.A. } \\
\end{array}$ & $\begin{array}{l}\text { Development of a technical } \\
\text { innovation audit. }\end{array}$ & 1996 & $\begin{array}{l}\text { Journal of product } \\
\text { innovation } \\
\text { management }\end{array}$ \\
\hline 169 & $\begin{array}{l}\text { Salvador, F. } \\
\text { Forza, C. } \\
\text { Rungtusanatham, } \\
\text { M. }\end{array}$ & $\begin{array}{l}\text { Modularity, product variety, } \\
\text { production volume, and } \\
\text { component sourcing: theorizing } \\
\text { beyond generic prescriptions. }\end{array}$ & 2002 & $\begin{array}{l}\text { Journal of } \\
\text { operations } \\
\text { management }\end{array}$ \\
\hline 153 & $\begin{array}{l}\text { Corbetta, G. } \\
\text { Salvato, C. }\end{array}$ & $\begin{array}{l}\text { Self-serving or self-actualizing? } \\
\text { Models of man and agency costs in }\end{array}$ & 2004 & $\begin{array}{l}\text { Entrepreneurship } \\
\text { theory and practice }\end{array}$ \\
\hline
\end{tabular}




\begin{tabular}{|c|c|c|c|c|}
\hline & & $\begin{array}{l}\text { different types of family firms: A } \\
\text { commentary on "comparing the } \\
\text { agency costs of family and non- } \\
\text { family firms: Conceptual issues } \\
\text { and exploratory evidence". }\end{array}$ & & \\
\hline 153 & $\begin{array}{l}\text { MacCormack, A. } \\
\text { Verganti, R. } \\
\text { Iansiti, M. }\end{array}$ & $\begin{array}{l}\text { Developing products on "Internet } \\
\text { time": The anatomy of a flexible } \\
\text { development process. }\end{array}$ & 2001 & $\begin{array}{l}\text { Management } \\
\text { science }\end{array}$ \\
\hline 138 & $\begin{array}{l}\text { Hoegl, M. } \\
\text { Weinkauf, K. } \\
\text { Gemuenden, } \\
\text { H.G. }\end{array}$ & $\begin{array}{l}\text { Interteam coordination, project } \\
\text { commitment, and teamwork in } \\
\text { multiteam R\&D projects: A } \\
\text { longitudinal study. }\end{array}$ & 2004 & $\begin{array}{l}\text { Organization } \\
\text { science }\end{array}$ \\
\hline 131 & $\begin{array}{l}\text { Colombo, M.G. } \\
\text { Delmastro, M. }\end{array}$ & $\begin{array}{l}\text { How effective are technology } \\
\text { incubators? Evidence from Italy. }\end{array}$ & 2002 & Research policy \\
\hline 122 & $\begin{array}{l}\text { Cova, B. } \\
\text { Pace, S. }\end{array}$ & $\begin{array}{l}\text { Brand community of convenience } \\
\text { products: new forms of customer } \\
\text { empowerment - the case "my } \\
\text { Nutella The Community". }\end{array}$ & 2006 & $\begin{array}{l}\text { European journal of } \\
\text { marketing }\end{array}$ \\
\hline 121 & $\begin{array}{l}\text { Bruni, A. } \\
\text { Gherardi, S. } \\
\text { Poggio, B. }\end{array}$ & $\begin{array}{l}\text { Doing gender, doing } \\
\text { entrepreneurship: An ethnographic } \\
\text { account of intertwined practices. }\end{array}$ & 2004 & $\begin{array}{l}\text { Gender work and } \\
\text { organization }\end{array}$ \\
\hline 121 & Lamming, R. & $\begin{array}{l}\text { Squaring lean supply with supply } \\
\text { chain management. }\end{array}$ & 1996 & $\begin{array}{l}\text { International } \\
\text { journal of } \\
\text { operations \& } \\
\text { production } \\
\text { management }\end{array}$ \\
\hline 117 & Verganti, R. & $\begin{array}{l}\text { Design, meanings, and radical } \\
\text { innovation: A metamodel and a } \\
\text { research agenda. }\end{array}$ & 2008 & $\begin{array}{l}\text { Journal of product } \\
\text { innovation } \\
\text { management }\end{array}$ \\
\hline
\end{tabular}

The immediate evidence arising is referred to authors' country of origin. In fact, taking into consideration 41 papers, 27 (65,85\%) of them come from Italian scholars and $14(34,15 \%)$ from non-Italian scholars.

\subsection{Authors Overview}

The second part of the analysis involves authors. Table 3 shows the most prolific authors with at least five indexed papers indexed in WOS Core Collection including co-authorships.

Table 3 - Most prolific authors, with at least five indexed papers

\begin{tabular}{|l|l|c|c|l|c|}
\hline$\#$ & Name & N. P. & $\#$ & Name & N. P. \\
\hline 1 & Chiesa, Vittorio & 17 & 24 & Spina, Gianluca & 6 \\
\hline 2 & Nosella, Anna & 13 & 25 & Gherardi, Silvia & 6 \\
\hline 3 & Colombo, Massimo G. & 12 & 26 & Goffin, Keith & 6 \\
\hline 4 & Ordanini, Andrea & 11 & 27 & Giangreco, Antonio & 6 \\
\hline 5 & Cagliano, Raffaella & 10 & 28 & Gualandris, Jury & 5 \\
\hline 6 & De Massis, Alfredo & 10 & 29 & Ghezzi, Antonio & 5 \\
\hline 7 & Danese, Pamela & 9 & 30 & Calabrese, Armando & 5 \\
\hline
\end{tabular}




\begin{tabular}{|l|l|l|l|l|c|}
\hline 8 & Corso, Mariano & 9 & 31 & Aloini, Davide & 5 \\
\hline 9 & Frattini, Federico & 9 & 32 & Salvato, Carlo & 5 \\
\hline 10 & Guenzi, Paolo & 8 & 33 & Borgonovo, Emanuele & 5 \\
\hline 11 & Bianchi, Mattia & 8 & 34 & Muffatto, Moreno & 5 \\
\hline 12 & De Toni, Alberto F. & 8 & 35 & Magnusson, Mats & 5 \\
\hline 13 & Martini, Antonella & 8 & 36 & Rossi-Lamastra, Cristina & 5 \\
\hline 14 & Zollo, Maurizio & 8 & 37 & Wright, Mike & 5 \\
\hline 15 & Verganti, Roberto & 8 & 38 & Bianchi, Carmine & 5 \\
\hline 16 & Luzzini, Davide & 7 & 39 & Caru, Antonella & 5 \\
\hline 17 & Gambardella, Alfonso & 7 & 40 & Rubera, Gaia & 5 \\
\hline 18 & Dell'Era, Claudio & 7 & 41 & Di Minin, Alberto & 5 \\
\hline 19 & Neirotti, Paolo & 7 & 42 & Priem, Richard L. & 5 \\
\hline 20 & Hoegl, Martin & 7 & 43 & Minichilli, Alessandro & 5 \\
\hline 21 & Frey, Marco & 7 & 44 & Coccia, Mario & 5 \\
\hline 22 & Sciascia, Salvatore & 6 & 45 & Azzone, Giovanni & 5 \\
\hline 23 & Pagani, Margherita & 6 & & & \\
\hline \multicolumn{4}{|l|}{} & & \multicolumn{4}{|}{ *N.P. is “number of papers". } \\
\hline
\end{tabular}

Table 4 shows the most cited authors with at least 200 citations, including co-authorships. On the table below we noted the same issue as Table 1 regarding the number of citations. For example, if we take into consideration the first author findable in Google Scholar, namely Lipparini Andrea, he had 3,161 citations in Google Scholar instead of 491 in WOS. Consistently with previous research, we argue that WOS Core Collection indicator is more precise and more reliable than Google Scholar because of its representation of only high impact researches (Meho and Yang, 2007).

Table 4 - Most cited authors, with at least two hundred citations

\begin{tabular}{|l|l|l|l|l|l|}
\hline$\#$ & Name & T.C. & $\#$ & Name & T.C. \\
\hline 1 & Chiesa, Vittorio & 701 & 17 & Gargiulo, Martin & 350 \\
\hline 2 & Verganti, Roberto & 671 & 18 & Spina, Gianluca & 336 \\
\hline 3 & Forza, Cipriano & 655 & 19 & Ordanini, Andrea & 322 \\
\hline 4 & Lipparini, Andrea & 491 & 20 & Corbetta, Guido & 300 \\
\hline 5 & Hoegl, Martin & 448 & 21 & Navarra, Pietro & 291 \\
\hline 6 & Gherardi, Silvia & 434 & 22 & Poggio, Barbara & 252 \\
\hline 7 & Colombo, Massimo G. & 417 & 23 & Zucchella, Antonella & 232 \\
\hline 8 & Gibbert, Michael & 403 & 24 & De Massis, Alfredo & 231 \\
\hline 9 & Lorenzoni, Gianni & 401 & 25 & Mazzola,Pietro & 231 \\
\hline 10 & Verona, Gianmarco & 401 & 26 & Zollo, Maurizio & 224 \\
\hline 11 & Frattini, Federico & 383 & 27 & Minichilli, Alessandro & 218 \\
\hline 12 & Salvato, Carlo & 382 & 28 & Greco, Salvatore & 217 \\
\hline 13 & Benassi, Mario & 370 & 29 & Grilli, Luca & 214 \\
\hline 14 & Bonaccorsi, Andrea & 367 & 30 & Speranza, Maria G. & 212 \\
\hline 15 & Cagliano, Raffaella & 365 & 31 & Capaldo, Antonio & 210 \\
\hline 16 & Salvador, Fabrizio & 352 & 32 & Noci, Giuliano & 206 \\
\hline & & \multicolumn{4}{|c}{ *T.C. is “total citations". } \\
\hline
\end{tabular}


Management lessons from Italy: a bibliometric analysis of top Italian based scholars and studies published from 1985 to 2015.

\subsection{Journals Overview}

The third part of our analysis involves journals; Table 5 shows journals with at least 10 papers, while Table 6 shows the most 50 cited journals.

Table 5 - List of journals with at least ten papers

\begin{tabular}{|c|c|c|c|c|c|}
\hline \# & Journal & T.C. & $\#$ & Journal & T.C. \\
\hline 1 & $\begin{array}{l}\text { European journal of operational } \\
\text { research }\end{array}$ & 106 & 27 & $\begin{array}{l}\text { Corporate governance-an } \\
\text { international review }\end{array}$ & 16 \\
\hline 2 & $\begin{array}{l}\text { International journal of } \\
\text { operations \& production } \\
\text { management }\end{array}$ & 72 & 28 & Industry and innovation & 15 \\
\hline 3 & $\begin{array}{l}\text { International journal of } \\
\text { technology management }\end{array}$ & 60 & 29 & $\begin{array}{l}\text { International journal of project } \\
\text { management }\end{array}$ & 15 \\
\hline 4 & Research policy & 42 & 30 & Family business review & 14 \\
\hline 5 & $\begin{array}{l}\text { Journal of product innovation } \\
\text { management }\end{array}$ & 41 & 31 & Journal of technology transfer & 14 \\
\hline 6 & Journal of business ethics & 38 & 32 & $\begin{array}{l}\text { Entrepreneurship theory and } \\
\text { practice }\end{array}$ & 13 \\
\hline 7 & $\begin{array}{l}\text { Industrial marketing } \\
\text { management }\end{array}$ & 34 & 33 & Journal of operations management & 13 \\
\hline 8 & Technovation & 31 & 34 & $\begin{array}{l}\text { Journal of small business } \\
\text { management }\end{array}$ & 13 \\
\hline 9 & $\begin{array}{l}\text { Journal of knowledge } \\
\text { management }\end{array}$ & 28 & 35 & Organization studies & 13 \\
\hline 10 & European management journal & 26 & 36 & Strategic management journal & 13 \\
\hline 11 & R \& D management & 26 & 37 & British journal of management & 12 \\
\hline 12 & Public management review & 25 & 38 & International business review & 12 \\
\hline 13 & $\begin{array}{l}\text { International journal of human } \\
\text { resource management }\end{array}$ & 23 & 39 & $\begin{array}{l}\text { Journal of organizational change } \\
\text { management }\end{array}$ & 12 \\
\hline 14 & Long range planning & 23 & 40 & $\begin{array}{l}\text { Journal of purchasing and supply } \\
\text { management }\end{array}$ & 12 \\
\hline 15 & Management decision & 23 & 41 & Business history & 11 \\
\hline 16 & Small business economics & 23 & 42 & $\begin{array}{l}\text { Business strategy and the } \\
\text { environment }\end{array}$ & 11 \\
\hline 17 & European management review & 22 & 43 & Industrial and corporate change & 11 \\
\hline 18 & Tourism management & 22 & 44 & Journal of intellectual capital & 11 \\
\hline 19 & Organization science & 21 & 45 & Management science & 11 \\
\hline 20 & $\begin{array}{l}\text { Technology analysis \& strategic } \\
\text { management }\end{array}$ & 20 & 46 & Total quality management & 11 \\
\hline 21 & $\begin{array}{l}\text { Total quality management } \& \\
\text { business excellence }\end{array}$ & 20 & 47 & $\begin{array}{l}\text { Business process management } \\
\text { journal }\end{array}$ & 10 \\
\hline 22 & $\begin{array}{l}\text { Knowledge management } \\
\text { research \& practice }\end{array}$ & 19 & 48 & Human resource management & 10 \\
\hline 23 & $\begin{array}{l}\text { Technological forecasting and } \\
\text { social change }\end{array}$ & 19 & 49 & $\begin{array}{l}\text { IEEE transactions on engineering } \\
\text { management }\end{array}$ & 10 \\
\hline 24 & Journal of nursing management & 18 & 50 & $\begin{array}{l}\text { International journal of } \\
\text { contemporary hospitality } \\
\text { management }\end{array}$ & 10 \\
\hline
\end{tabular}




\begin{tabular}{|l|l|l|l|l|l|}
\hline 25 & Journal of business research & 17 & 51 & $\begin{array}{l}\text { Journal of engineering and } \\
\text { technology management }\end{array}$ & 10 \\
\hline 26 & $\begin{array}{l}\text { Supply chain management-an } \\
\text { international journal }\end{array}$ & 17 & & & *T.C. is "total citations". \\
\hline
\end{tabular}

In order to ensure a wider perspective about the journals, we included also the journals with the total number of citations (Table 6) to highlight where the Italian scholars and Italian based studies have more relevance.

Table 6 - List of the fifty most cited journals

\begin{tabular}{|c|c|c|c|c|c|}
\hline \# & Journal & T.C. & \# & Journal & T.C. \\
\hline 1 & $\begin{array}{l}\text { European journal of } \\
\text { operational research }\end{array}$ & 1791 & 26 & Small business economics & 249 \\
\hline 2 & $\begin{array}{l}\text { International journal of } \\
\text { operations \& production } \\
\text { management }\end{array}$ & 1726 & 27 & $\begin{array}{l}\text { Corporate governance-an } \\
\text { international review }\end{array}$ & 242 \\
\hline 3 & Organization science & 1263 & 28 & Journal of business research & 180 \\
\hline 4 & Research policy & 1155 & 29 & Journal of world business & 177 \\
\hline 5 & $\begin{array}{l}\text { Journal of product innovation } \\
\text { management }\end{array}$ & 1123 & 30 & Public management review & 174 \\
\hline 6 & Strategic management journal & 1029 & 31 & European journal of marketing & 170 \\
\hline 7 & Journal of business ethics & 596 & 32 & International business review & 163 \\
\hline 8 & $\begin{array}{l}\text { Journal of international } \\
\text { business studies }\end{array}$ & 583 & 33 & $\begin{array}{l}\text { Technological forecasting and } \\
\text { social change }\end{array}$ & 160 \\
\hline 9 & $\begin{array}{l}\text { Journal of operations } \\
\text { management }\end{array}$ & 553 & 34 & Operations research & 158 \\
\hline 10 & Technovation & 527 & 35 & $\begin{array}{l}\text { Journal of knowledge } \\
\text { management }\end{array}$ & 153 \\
\hline 11 & $\begin{array}{l}\text { Entrepreneurship theory and } \\
\text { practice }\end{array}$ & 478 & 36 & $\begin{array}{l}\text { Omega-international journal of } \\
\text { management science }\end{array}$ & 148 \\
\hline 12 & R \& D management & 474 & 37 & Journal of nursing management & 146 \\
\hline 13 & $\begin{array}{l}\text { Industrial marketing } \\
\text { management }\end{array}$ & 416 & 38 & $\begin{array}{l}\text { Journal of organizational change } \\
\text { management }\end{array}$ & 146 \\
\hline 14 & $\begin{array}{l}\text { International journal of } \\
\text { technology management }\end{array}$ & 390 & 39 & $\begin{array}{l}\text { International journal of human } \\
\text { resource management }\end{array}$ & 144 \\
\hline 15 & Management science & 351 & 40 & Management decision & 143 \\
\hline 16 & Organization studies & 347 & 41 & Journal of service research & 139 \\
\hline 17 & Family business review & 330 & 42 & European management journal & 134 \\
\hline 18 & Tourism management & 326 & 43 & $\begin{array}{l}\text { Journal of engineering and } \\
\text { technology management }\end{array}$ & 134 \\
\hline 19 & $\begin{array}{l}\text { Academy of management } \\
\text { review }\end{array}$ & 308 & 44 & $\begin{array}{l}\text { International journal of project } \\
\text { management }\end{array}$ & 128 \\
\hline 20 & Long range planning & 307 & 45 & Gender work and organization & 126 \\
\hline 21 & $\begin{array}{l}\text { Supply chain management-an } \\
\text { international journal }\end{array}$ & 297 & 46 & Journal of management & 123 \\
\hline 22 & $\begin{array}{l}\text { Journal of management } \\
\text { studies }\end{array}$ & 282 & 47 & California management review & 121 \\
\hline 23 & European management review & 279 & 48 & Harvard business review & 121 \\
\hline 24 & Journal of business venturing & 273 & 49 & $\begin{array}{l}\text { Journal of purchasing and supply } \\
\text { management }\end{array}$ & 114 \\
\hline
\end{tabular}




\begin{tabular}{|l|l|l|l|l|l|}
\hline 25 & Human relations & 261 & 50 & $\begin{array}{l}\text { Knowledge management research } \\
\text { \& practice }\end{array}$ & 111 \\
\hline \multicolumn{4}{|c|}{ *T.C. is "total citations". } \\
\hline
\end{tabular}

As immediate evidence, it is possible to see that despite a different unit of measure in Table 5 and Table 6 , that respectively represent the concentration of papers in term of journals and the aggregate impact of papers in terms of journals, the main field of research is focused on innovation and technology.

This evidence is also confirmed by the following bibliometric analysis who shows the knowledge structure of data taken into consideration.

\section{Bibliometric Keyword Analysis}

\subsection{Method}

After the brief presentation of papers, authors, and journals in this field of research, to achieve the aim of mapping the research streams by an extensive number of papers, we use the text-mining routine VOSviewer 1.6.5 (Van Eck and Waltman, 2010).

The map built by the text-mining routine is a plot in which keywords' distance can be interpreted as a sign of the relatedness of the terms. The smaller the distance is between keywords, the stronger the keywords are related to each other. The keywords' relatedness is determined on cooccurrences in documents (Van Eck et al., 2010).

After the analysis of keywords, the next step involves the cluster analysis, in particular, the measure of intra- and inter-cluster diversity with the aim of better understanding knowledge base diversity within each cluster (Van Eck and Waltman, 2014).

The cluster analysis shows knowledge-base diversity besides each cluster. When keywords belong to the same cluster they are strongly linked as a group. It shows that a cluster represents a stream of research or particular topic on a similarity base. However, the proximity needs to be considered in cluster visualization. In particular, there are several cases where an item belongs to a cluster, but it is in the proximity to another cluster. In those cases, even though the items do not appear in the same cluster, they are fairly related to each other but not with the strength necessary to belong to the same cluster. This issue happened because of the unfeasibility to show the VOS output with the third dimension (Van Eck and Waltman, 2007). Last, the brightness of a point represents the intensity of it in terms of several occurrences, showing the importance of itself in the plot. 
In conclusion, to settle to what extends a certain cluster is more diverse than another one the script perform a t-test to exam the differences in their diversity (Van Eck and Waltman, 2009; Waltman et al., 2010).

Regarding the keyword analysis taken into consideration, we included chief authors' keywords that appear (occurrences) at least five times in the dataset. However, in order to ensure the reliability of the representation, a manual selection and cleaning is done independently by two authors. After this step, we have compared the results and made the final keywords selection.

\subsection{Keywords Cluster Overview}

The figure below (Figure 2) shows the results for keyword clustering. From the figure, it can be appreciated how the words which belong to the same sphere have the tendency to appear together.

Figure 2 - Graphical result of keywords analysis

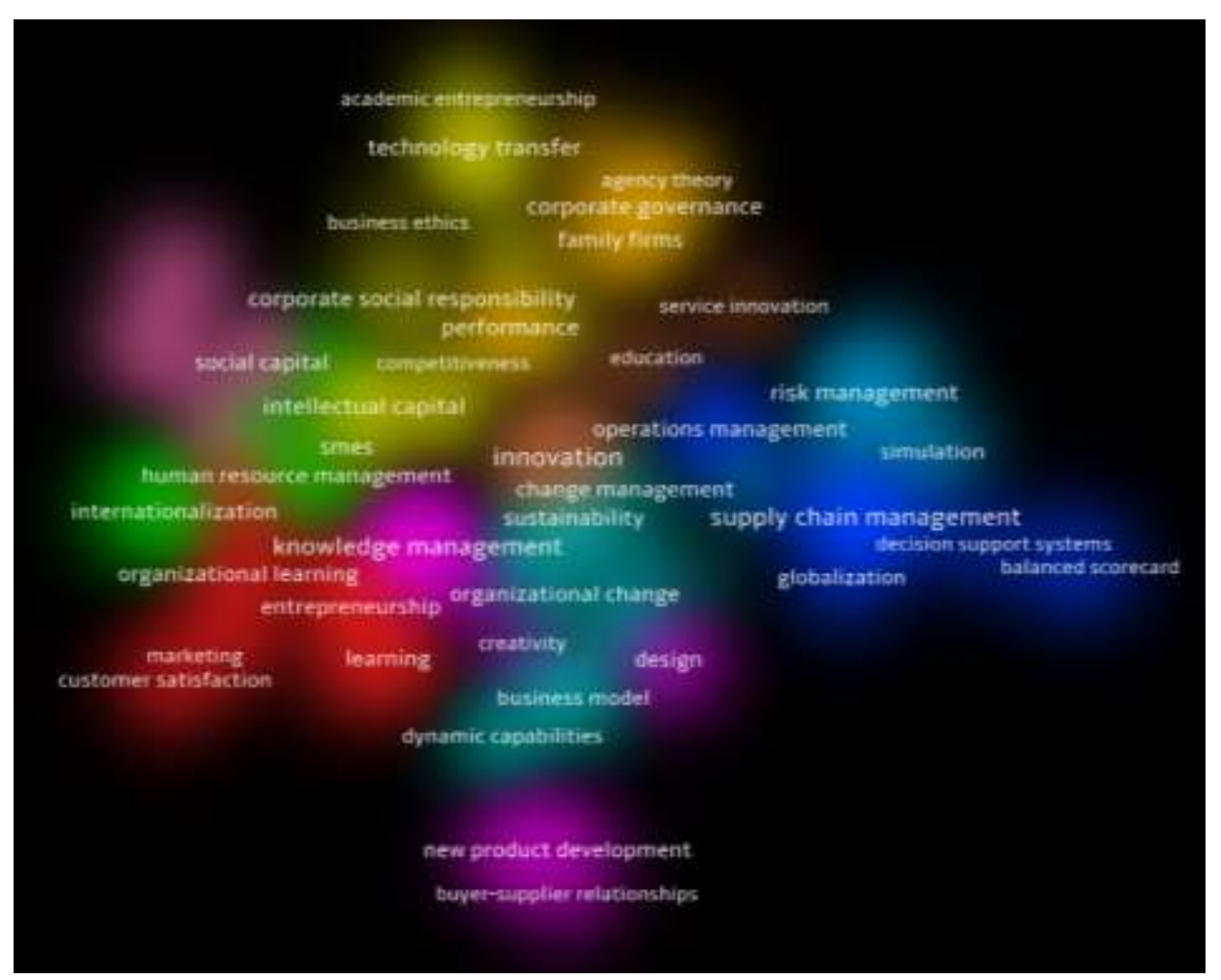

Table 7 briefly summarizes the cluster aggregation in order to ensure a clearer understanding. 
Table 7 - Summary of keywords clustering

\begin{tabular}{|c|c|}
\hline Cluster & Keywords \\
\hline 1 & $\begin{array}{l}\text { absorptive capacity, communication, customer satisfaction, entrepreneurship, } \\
\text { ethnography, human capital, knowledge transfer, learning, marketing, mergers and } \\
\text { acquisitions, organizational learning, social networks, strategic alliances }\end{array}$ \\
\hline 2 & $\begin{array}{l}\text { alliances, ambidexterity, human resource management, internationalization, open } \\
\text { innovation, patents, R\&D, stakeholder management }\end{array}$ \\
\hline 3 & $\begin{array}{l}\text { balanced scorecard, decision support systems, globalization, operations management, } \\
\text { purchasing, supplier relations, supply chain management, system dynamics }\end{array}$ \\
\hline 4 & $\begin{array}{l}\text { academic entrepreneurship, accounting, health care, intellectual capital, international } \\
\text { management, knowledge sharing, technology transfer }\end{array}$ \\
\hline 5 & $\begin{array}{l}\text { buyer-supplier relationships, creativity, design, knowledge creation, knowledge } \\
\text { management, new product development, project management }\end{array}$ \\
\hline 6 & $\begin{array}{l}\text { business model, dynamic capabilities, logistics, manufacturing, strategic } \\
\text { management, strategy, sustainability }\end{array}$ \\
\hline 7 & $\begin{array}{l}\text { decision support system, environmental management, finance, risk management, } \\
\text { simulation, sustainable development }\end{array}$ \\
\hline 8 & $\begin{array}{l}\text { agency theory, corporate governance, family firms, family involvement, ownership } \\
\text { structure, performance }\end{array}$ \\
\hline 9 & business ethics, competitiveness, corporate social responsibility, CSR, SMEs \\
\hline 10 & $\begin{array}{l}\text { competitive advantage, intangible assets, job satisfaction, resource-based view, social } \\
\text { capital }\end{array}$ \\
\hline 11 & education, innovation, service innovation, social media \\
\hline 12 & change management, decision making, heuristics, organizational change \\
\hline
\end{tabular}

Twelve clusters seem to emerge. Although some clusters result to be wide, such as Cluster 1, which contains keywords such as absorptive capacity, entrepreneurship, knowledge transfer, marketing, and communication, other clusters reveal a more focused result, such as Cluster 11 and 12 . However, it is clear how Italian management research has spanned across most of the areas of research considered at the global level, in particular, we noted the predominance of strategy (Cluster 1, 2, 5, 6, 8, 10), innovation (Cluster 2, 4, 11), operations and logistics (Cluster 3), and business ethics (Cluster 9).

\subsection{Keywords Density Overview}

A deeper analysis is portrayed by the figure below, which shows the relative importance of the keywords, in terms of their density, where the red color shows high density, the yellow color shows a medium density and the green a lower density (Van Eck et al., 2010a). 
Figure 3 - Graphical representation of keywords occurrences

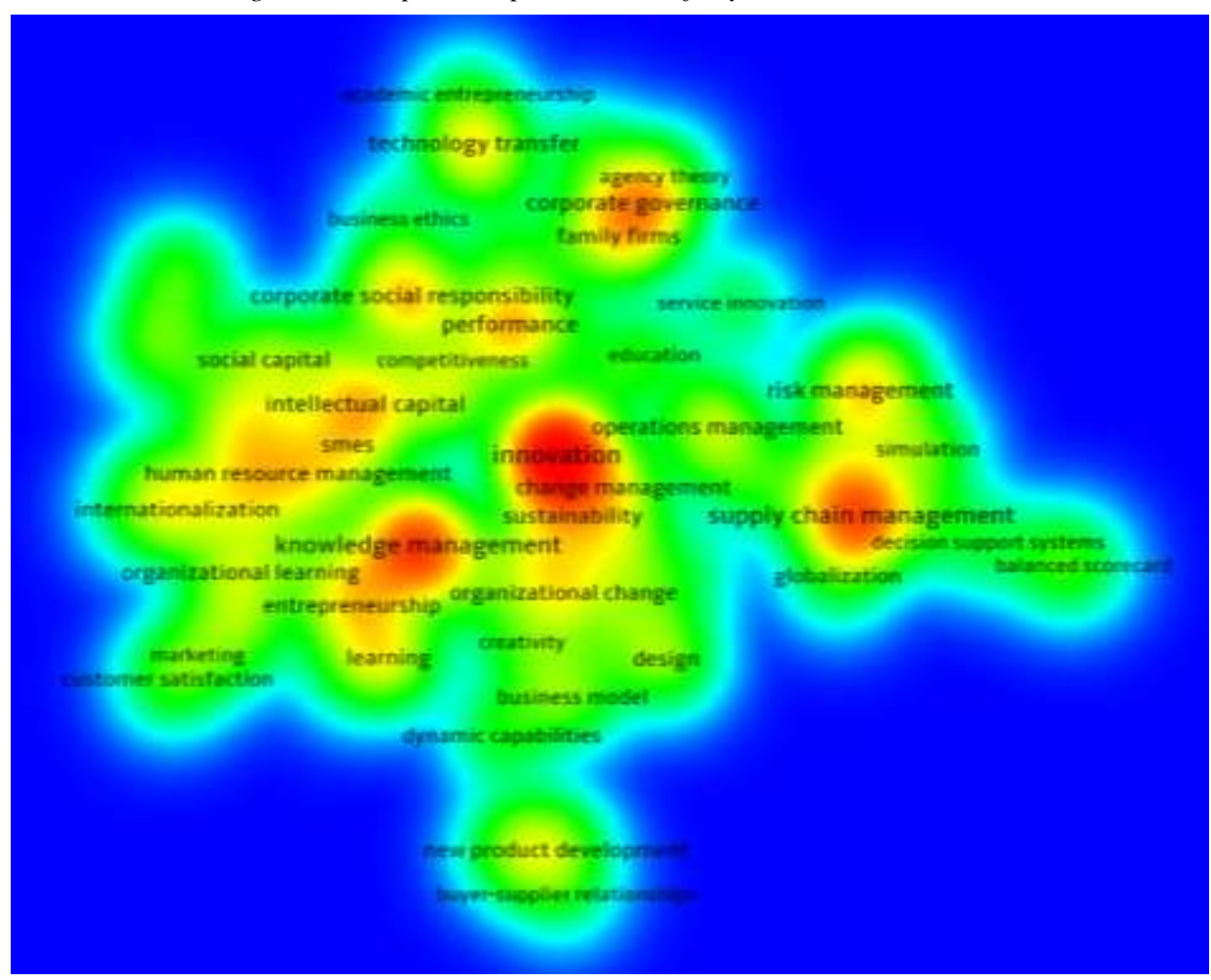

The table below (Table 8) shows the aggregate number of occurrences per cluster keywords had.

Table 8 - Numerical representation of keywords occurrences

\begin{tabular}{|r|l|c|r|l|c|}
\hline$\#$ & Keyword & OCC. & $\#$ & Keyword & OCC. \\
\hline 1 & innovation & 69 & 41 & knowledge creation & 7 \\
\hline 2 & knowledge management & 45 & 42 & ownership structure & 7 \\
\hline 3 & supply chain management & 42 & 43 & strategy & 7 \\
\hline 4 & corporate governance & 27 & 44 & supplier relations & 7 \\
\hline 5 & performance & 26 & 45 & sustainable development & 7 \\
\hline 6 & corporate social responsibility & 24 & 46 & agency theory & 6 \\
\hline 7 & intellectual capital & 22 & 47 & ambidexterity & 6 \\
\hline 8 & risk management & 21 & 48 & balanced scorecard & 6 \\
\hline 9 & technology transfer & 19 & 49 & creativity & 6 \\
\hline 10 & learning & 18 & 50 & decision support systems & 6 \\
\hline 11 & entrepreneurship & 17 & 51 & education & 6 \\
\hline 12 & operations management & 17 & 52 & ethnography & 6 \\
\hline 13 & organizational change & 17 & 53 & finance & 6 \\
\hline 14 & sustainability & 16 & 54 & human capital & 6 \\
\hline 15 & internationalization & 15 & 55 & logistics & 6 \\
\hline 16 & knowledge sharing & 15 & 56 & manufacturing & 6 \\
\hline
\end{tabular}




\begin{tabular}{|l|l|c|c|l|c|}
\hline 17 & family firms & 14 & 57 & marketing & 6 \\
\hline 18 & human resource management & 14 & 58 & mergers and acquisitions & 6 \\
\hline 19 & design & 13 & 59 & patents & 6 \\
\hline 20 & organizational learning & 13 & 60 & purchasing & 6 \\
\hline 21 & social capital & 13 & 61 & R\&D & 6 \\
\hline 22 & change management & 12 & 62 & service innovation & 6 \\
\hline 23 & new product development & 12 & 63 & social media & 6 \\
\hline 24 & project management & 12 & 64 & social networks & 6 \\
\hline 25 & SMEs & 12 & 65 & strategic alliances & 6 \\
\hline 26 & knowledge transfer & 11 & 66 & system dynamics & 6 \\
\hline 27 & open innovation & 11 & 67 & academic entrepreneurship & 5 \\
\hline 28 & competitive advantage & 10 & 68 & accounting & 5 \\
\hline 29 & decision making & 10 & 69 & alliances & 5 \\
\hline 30 & job satisfaction & 10 & 70 & business ethics & 5 \\
\hline 31 & resource-based view & 10 & 71 & buyer-supplier relationships & 5 \\
\hline 32 & strategic management & 10 & 72 & communication & 5 \\
\hline 33 & customer satisfaction & 9 & 73 & competitiveness & 5 \\
\hline 34 & simulation & 9 & 74 & CSR & 5 \\
\hline 35 & business model & 8 & 75 & decision support system & 5 \\
\hline 36 & dynamic capabilities & 8 & 76 & family involvement & 5 \\
\hline 37 & environmental management & 8 & 77 & heuristics & 5 \\
\hline 38 & absorptive capacity & 7 & 78 & intangible assets & 5 \\
\hline 39 & globalization & 7 & 79 & international management & 5 \\
\hline 40 & health care & 7 & 80 & stakeholder management & 5 \\
\hline & & $*$ “OCC.” is the number of keyword occurrences. \\
\hline
\end{tabular}

As a result, it is more clear that most Italian research has focused on innovation, knowledge management, supply chain management and corporate governance (Bonaccorsi, 1992; Lorenzoni and Lipparini, 1999; Gargiulo and Benassi, 2000). Areas that are less investigated and might make up promising research avenues are business ethics, service innovation and academic entrepreneurship (Ordanini and Parasuraman, 2008; Audretsch et al., 2015; Garegiani et al., 2015).

\subsection{Keywords Average Novelty}

With the third level of analysis, we finally represent the average novelty of keywords expressed in years. The plot and the table (Figure 4 and Table 9) are based on the same keywords' dataset of the above two analyses. Here, the labels' colors represent the average age of keywords. In particular, the more the color is cold (blue, light blue), the more the keyword is outdated. On the contrary, the more the color is warm (yellow, orange, and red) the more the keyword is recent.

Indeed, the keywords taken in consideration are not older than 2004. This relates to the scientific proliferation of the last ten years, which we already 
mentioned in paragraph two. Nevertheless, eleven years of data visualization is still useful to analyze the recent field evolution.

Figure 4-Graphical representation of keywords average novelty

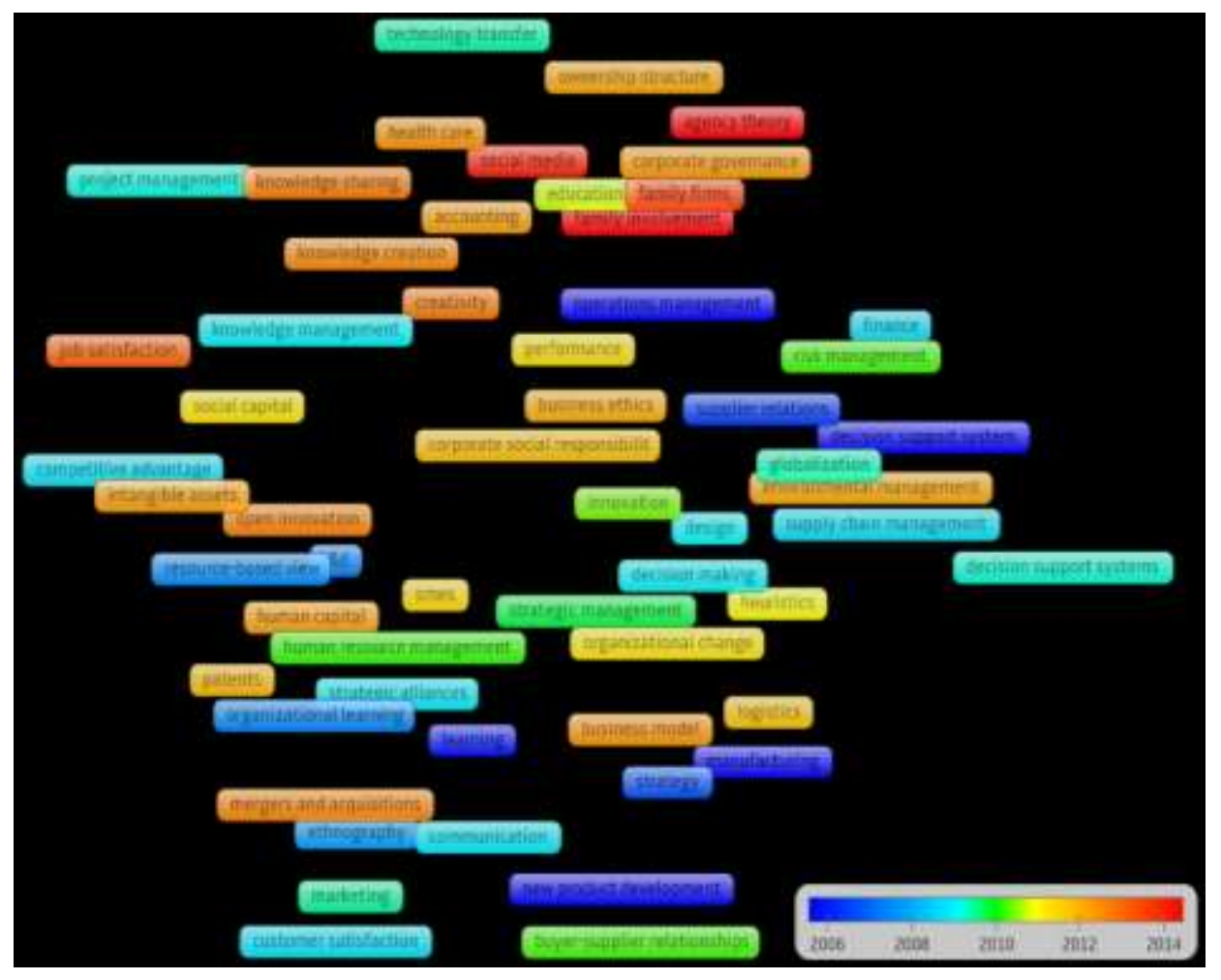

The table below (Table 9) shows the average keywords' year and "A.Y." represents this value.

Table 9 - Numerical representation of keywords average novelty

\begin{tabular}{|r|l|c|r|l|c|}
\hline \multicolumn{1}{|l|}{$\#$} & Keyword & A.Y. & $\#$ & Keyword & A.Y. \\
\hline 1 & agency theory & 2014,33 & 41 & social capital & 2011,08 \\
\hline 2 & family involvement & 2014,20 & 42 & organizational change & 2011,06 \\
\hline 3 & absorptive capacity & 2014,16 & 43 & entrepreneurship & 2010,80 \\
\hline 4 & social media & 2013,67 & 44 & heuristics & 2010,80 \\
\hline 5 & ambidexterity & 2013,33 & 45 & education & 2010,67 \\
\hline 6 & family firms & 2013,29 & 46 & innovation & 2010,36 \\
\hline 7 & service innovation & 2013,17 & 47 & buyer-supplier relationships & 2010,20 \\
\hline 8 & stakeholder management & 2013,00 & 48 & risk management & 2010,19 \\
\hline 9 & dynamic capabilities & 2012,88 & 49 & human resource management & 2010,14 \\
\hline 10 & social networks & 2012,83 & 50 & strategic management & 2009,80 \\
\hline 11 & competitiveness & 2012,80 & 51 & marketing & 2009,50 \\
\hline 12 & job satisfaction & 2012,80 & 52 & technology transfer & 2009,47 \\
\hline 13 & creativity & 2012,50 & 53 & globalization & 2009,43 \\
\hline
\end{tabular}




\begin{tabular}{|l|l|l|l|l|l|}
\hline 14 & knowledge sharing & 2012,47 & 54 & decision support systems & 2009,33 \\
\hline 15 & sustainable development & 2012,43 & 55 & project management & 2009,27 \\
\hline 16 & academic entrepreneurship & 2012,40 & 56 & design & 2009,15 \\
\hline 17 & sustainability & 2012,38 & 57 & knowledge management & 2009,11 \\
\hline 18 & open innovation & 2012,36 & 58 & decision making & 2009,10 \\
\hline 19 & mergers and acquisitions & 2012,33 & 59 & communication & 2009,00 \\
\hline 20 & intellectual capital & 2012,32 & 60 & strategic alliances & 2009,00 \\
\hline 21 & knowledge creation & 2012,29 & 61 & competitive advantage & 2008,90 \\
\hline 22 & CSR & 2012,20 & 62 & customer satisfaction & 2008,89 \\
\hline 23 & health care & 2012,14 & 63 & supply chain management & 2008,88 \\
\hline 24 & business model & 2012,13 & 64 & finance & 2008,83 \\
\hline 25 & change management & 2012,08 & 65 & system dynamics & 2008,67 \\
\hline 26 & corporate governance & 2012,04 & 66 & knowledge transfer & 2008,40 \\
\hline 27 & accounting & 2012,00 & 67 & international management & 2008,20 \\
\hline 28 & human capital & 2012,00 & 68 & ethnography & 2008,00 \\
\hline 29 & intangible assets & 2012,00 & 69 & resource-based view & 2007,78 \\
\hline 30 & environmental management & 2011,88 & 70 & organizational learning & 2007,69 \\
\hline 31 & ownership structure & 2011,86 & 71 & R\&D & 2007,67 \\
\hline 32 & alliances & 2011,80 & 72 & purchasing & 2007,60 \\
\hline 33 & business ethics & 2011,80 & 73 & simulation & 2007,22 \\
\hline 34 & internationalization & 2011,80 & 74 & strategy & 2007,00 \\
\hline 35 & patents & 2011,67 & 75 & supplier relations & 2006,71 \\
\hline 36 & corporate social responsibility & 2011,54 & 76 & learning & 2006,17 \\
\hline 37 & balanced scorecard & 2011,50 & 77 & new product development & 2005,73 \\
\hline 38 & logistics & 2011,50 & 78 & decision support system & 2005,40 \\
\hline 39 & SMEs & 2011,25 & 79 & operations management & 2004,00 \\
\hline 40 & performance & 2011,15 & 80 & manufacturing & 2003,83 \\
\hline & & & & $*$ A.Y. is average keyword's year \\
\hline
\end{tabular}

Specifically, regarding to the above figure (Figure 4), it highlights several interesting insights. First, as the image suggests, it is possible to divide the data in quartiles.

1. Dark blue and blue: $2005-2007$

2. Light blue and green: $2008-2010$

3. Yellow and orange: $2011-2013$

4. Red: $2014-2015$

Thus, it is possible to see that keywords which are related to the engineering side of management (e.g. operations management, new product development, and manufacturing) are in the older quartile (2005 - 2007, dark blue and blue). If we move to the second quartile (2008 - 2010, light blue and green) is possible to see keywords including technology transfer, supply chain management, innovation etc. This evidence is in line with the results of the previous analysis.

However, taking into consideration the third and fourth quartile, respectively 2011-2013 (yellow and orange) and 2014-2015 (red), we can witness to a radical change in keywords. We can notice a switch to more typical management topics such as social capital, corporate social 
responsibility, business model, and corporate governance. Finally, is possible to note that the most recent keywords highlight a focus on family firms (family firms and family involvement) and to social media creating possible future topics for Italian studies on management.

\section{Conclusion}

With this paper, the authors have taken into consideration the most relevant scholars and studies based on the Italian context. Indeed, the research query extracts all the scholars affiliated with an Italian university. In order to be more accurate, the research string also takes into consideration the researches based in the Italian context. The reason behind this choice could be explained because of a considerable number of Italian researchers are affiliated with non-Italian institutions. However, a large part of them remains involved in Italian-related projects.

In the first part, the authors stressed out the data to give a snapshot of the actual situation using classic bibliometric data. In the second part, namely paragraph 3, the data are processed to extract useful insights. In fact, keyword analysis highlights the streams inside the management field where scholars have focused their attention.

In particular, the analysis shows that innovation plays a major role in Italian studies on management. Immediately after, knowledge management and supply chain management are playing a relevant role in Italian scholars' topic selection. The other topics are following with a relevant difference. The evidence is also confirmed by the analysis of most cited journals.

Second, the last of the three levels of analysis highlight the medium age of the keywords. This representation clearly helps to identify on which topic Italian scholars were focused and which are the most recent trends. In fact, despite their relevance in terms of occurrences, the more recent papers handle topics such as agency theory, family involvement, absorptive capacity, social media, family firms, service innovation, stakeholder management, and dynamic capabilities. Thus, this evidence remakes that innovation as key research area remains the most important trending topic, but additional streams of literature are approaching the future, especially regarding family firms. We can argue that there are several promising research avenues, namely business ethics, service innovation, and academic entrepreneurship.

Thus, with this paper, we have contributed to the extant Italian literature in two ways. First, we gave a brief and easy to examine report about the stateof-the art of thirty years of research in management. In fact, with the first part of the present research, we gave the opportunity to immediate recognize the most influential papers, authors, and journals. 
Second, the keywords analysis has reinforced the examination of the extant literature but it also gave some useful insights about the trending topics for the near future which could help the researcher settle their research agenda with the most promising topic for the future.

In conclusion, this work has the typical limitation of a bibliometric study. In particular, the fact of taking in consideration a vast amount of papers (1,665 in this case) does not permit deepening all the literature but only to offer a wider and general perspective on the present field of study. 


\section{References}

Audretsch, D. B., Lehmann, E. E., and Paleari, S. (2015) 'Academic policy and entrepreneurship: a European perspective'. The Journal of Technology Transfer, Vol. 40 No. 3, pp., 363-368.

Bendixen, M., and Sandler, M. (1995) 'Converting verbal scales to interval scales using correspondence analysis', Management Dynamics: contemporary research, Vol. 4 No. 1, pp. 32-50.

Bonaccorsi, A. (1992) 'On the relationship between firm size and export intensity', Journal of international business studies, Vol. 23 No. 4, pp. 605-635.

Carmona, S. (2006) 'The history of management accounting in France, Italy, Portugal, and Spain', Handbooks of management accounting research, Vol. 2, pp. 905-922.

Chang, Y. W., Huang, M. H., and Lin, C. W. No. 2015) 'Evolution of research subjects in library and information science based on keyword, bibliographical coupling, and co-citation analyses', Scientometrics, Vol. 105 No. 3, pp. 2071-2087.

Caprara, U. (1961) Gino Zappa, L'Uomo, Giuffré: Milano.

Coda, V. (2002) 'L'Economia aziendale nella seconda metà degli anni '50: una rivisitazione delle 'Produzioni' e dell'opera postuma di Gino Zappa', Contabilità e Cultura Aziendale, Vol. 4, No. 1

Dabic, M., González-Loureiro, M., \& Furrer, O. (2014). Research on the strategy of multinational enterprises: key approaches and new avenues, Business Research Quarterly, 17(2): 129-148.

Dabic, M., González-Loureiro, M., \& Harvey, M. (2015). Evolving research on expatriates: what is 'known'after four decades (1970-2012). The International Journal of Human Resource Management, 26(3), 316-337

Fagerberg, J., Fosaas, M., and Sapprasert, K. (2012) 'Innovation: Exploring the knowledge base', Research Policy, Vol. 41, pp. 1132-1153.

Franceschet, M. (2010) 'A comparison of bibliometric indicators for computer science scholars and journals on Web of Science and Google Scholar', Scientometrics, Vol. 83 No. 1, pp. 243-258.

Garfield, E. (1990) 'Keywords Plus®: ISI's breakthrough retrieval method. Part 1. Expanding your searching power on Current Contents on Diskette', Current Contents®, Vol. 1, No. 32, pp. 5-9. 
Gargiulo, M., and Benassi, M. (2000) 'Trapped in your own net? Network cohesion, structural holes, and the adaptation of social capital', Organization science, Vol. 11 No. 2, pp. 183-196.

Hofmann, M., and Klinkenberg, R. (2013) 'RapidMiner: Data mining use cases and business analytics applications'. CRC Press

Hsieh, P. N., and Chang, P. L. (2009) 'An assessment of world-wide research productivity in production and operations management', International Journal of Production Economics, Vol. 120, pp. 540-551.

Khan, G. F., and Wood, J. (2015) 'Information technology management domain: emerging themes and keyword analysis', Scientometrics, Vol. 105 No. 2, pp. 959-972.

Landström, H., Harirchi, G., and Aström, F. (2012) 'Entrepreneurship: Exploring the knowledge base', Research Policy, Vol. 41, pp. 11541181.

Lorenzoni, G., and Lipparini, A. (1999) 'The leveraging of interfirm relationships as a distinctive organizational capability: a longitudinal study', Strategic Management Journal, Vol. 20 No. 4, pp. 317-338.

Leydesdorff, L., Carley, S., and Rafols, I. (2013) 'Global maps of science based on the new Web-of-Science categories', Scientometrics, Vol. 94 No. 2, pp. 589-593.

Marzi, G., Rialti, R., Dabic M., and Caputo, A. (2017). 'A Mixed Methods Bibliometric Investigation of the World Review of Entrepreneurship, Management and Sustainable Development: from qualitative to quantitative data', World Review of Entrepreneurship, Management and Sustainable Development, Forthcoming

Meho, L. I., and Yang, K. (2007) 'Impact of data sources on citation counts and rankings of LIS faculty: Web of Science versus Scopus and Google Scholar', Journal of the American society for information science and technology, Vol. 58, No. 13, pp. 2105-2125.

Ordanini, A., and Parasuraman, A. (2010) 'Service innovation viewed through a service-dominant logic lens: a conceptual framework and empirical analysis', Journal of Service Research, Vol. 14, No. 2, pp. 323.

Podsakoff, P. M., MacKenzie, S. B., Podsakoff, N. P., and Bachrach, D. G. (2008) 'Scholarly influence in the field of management: A bibliometric analysis of the determinants of university and author impact in the 
management literature in the past quarter century', Journal of Management, Vol. 1, No. 34, pp. 641-720.

$\mathrm{Su}, \mathrm{H}$. N., and Lee, P. C. (2010) 'Mapping knowledge structure by keyword co-occurrence: a first look at journal papers in Technology Foresight', Scientometrics, Vol. 85, No. 1, pp. 65-79.

Van Eck, N. J., and Waltman, L. (2009) 'How to normalize cooccurrence data? An analysis of some well-known similarity measures', Journal of the American Society for Information Science and Technology, Vol. 60 No. 8, pp. 1635-1651.

Van Eck, N. J., and Waltman, L. (2010) 'Software survey: VOSviewer, a computer program for bibliometric mapping', Scientometrics, Vol. 84 No. 2, pp. 523-538.

Van Eck, N. J., Waltman, L., Dekker, R., and van den Berg, J. (2010) 'A comparison of two techniques for bibliometric mapping: Multidimensional scaling and VOS', Journal of the American Society for Information Science and Technology, Vol. 61, No. 12, pp. 2405-2416.

Van Eck, N. J., and Waltman, L. (2014) 'Visualizing bibliometric networks', In Measuring scholarly impact, Springer International Publishing, pp. 285-320

Yoon, B., Lee, S., and Lee, G. (2010) 'Development and application of a keyword-based knowledge map for effective R\&D planning', Scientometrics, Vol. 85, No. 3, pp. 803-820.

Waltman, L., van Eck, N. J., and Noyons, E. C. (2010) 'A unified approach to mapping and clustering of bibliometric networks', Journal of Informetrics, Vol. 4, No. 4, pp. 629-635.

Wren, D. A. (2005) The history of management thought. John Wiley \& Sons.

Zappa, G. (1927), 'Tendenze nuove negli studi di ragioneria', Annuario del r. Istituto Superiore di Scienze Economiche e Commerciali di Venezia per gli Anni Accademici, 1925-26 \& 1926-27, pp. 29-62.

Zhang, J., Yu, Q., Zheng, F., Long, C., Lu, Z., and Duan, Z. (2015, in press) 'Comparing keywords plus of WOS and author keywords: a case study of patient adherence research', Journal of the Association for Information Science and Technology. 